\title{
DUDI MAIA ROSA
}

A fresta de uma porta, a escada de um porão, cenas de filmes: essas são algumas das imagens que integram Cábulas, exposição composta por sete telas que Dudi Maia Rosa apresenta no Centro Universitário Maria Antonia. O nome escolhido pelo artista é uma alusão direta às ocasiões em que, quando jovem, cabulava aulas na escola e ia passear por diversos lugares da cidade de São Paulo.

Essa experiência, segundo Dudi, ajudou a formar, anos mais tarde, um conjunto de referências que agora são utilizadas como ponto de partida para o desenvolvimento desses trabalhos. "É quase um testemunho. Quando estava vivenciando uma cábula, eu não podia me pronunciar, mas agora queria que isso fosse tão visível quanto um cinema, tanto quanto uma situação explícita.”

Existem, assim, várias narrativas implicadas nesses trabalhos, até porque as telas não tratam somente de lembranças do artista, mas também de uma série de representações familiares, que remetem ao universo cultural dos desenhos animados e das histórias infantis e correspondem a uma espécie de arquétipo coletivo, de memória compartilhada. É o caso, por exemplo, da tela que retrata uma figura feminina que lembra as personagens dos contos de fadas.

Dudi enxerga nessas referências não só fontes temáticas como também formais: "Uma vez o [Carlos] Fajardo, falou uma coisa de que eu gostei bastante: toda herança cromática que temos hoje vem ou do Walt Disney ou do Matisse. Acho que o desenho animado, o Tom e Jerry, talvez tenha pra mim, cromaticamente, um impacto emocional insuperável”.

A construção dessas imagens até chegar às telas é desenvolvida por Dudi Maia Rosa a partir de escolhas estéticas e técnicas inusuais, conferindo talvez algum estranhamento a um espectador desavisado. Se observadas de certa distância, as telas assemelham-se a pinturas tradicionais, como óleo e aquarela. Mera impressão: um olhar mais atento é capaz de revelar que os quadros são, na verdade, resultado de uma técnica particular de produção, na qual estão envolvidos não somente o trabalho manual como o de reprodutibilidade técnica. Além disso, a perspectiva adotada nas imagens das obras expostas apresenta ângulos inusitados em relação à visão mais tradicional do que seria o enquadramento de uma cena. Em outras palavras, os trabalhos envolvem uma "subversão da objetividade", como afirma o próprio artista.

O processo de elaboração dessas obras começa com a escolha de temas que servirão como base para sua composição e que surgem dos mais diversos contextos: são stills de desenho animado, pinturas a óleo e aquarelas já feitas 
pelo artista, entre outras fontes variadas. As imagens são trabalhadas manual e digitalmente, sendo posteriormente impressas em tela com tinta solvente, numa impressora a jato de tinta. O produto resultante desse processo é montado em chassi de madeira e pode ainda ser modificado à mão pelo artista. Comentando seu interesse pela utilização combinada dessas técnicas, Dudi Maia Rosa parafraseia Georges Braque: “a questão não é romper os limites da pintura, mas sim explorar esses limites. E eu entendo que isso também cabe a mim".

Durante toda a visita feita a seu ateliê, e especialmente ao falar sobre seu envolvimento com a pintura, Dudi revela seu gosto por analogias e citações. Ao sintetizar o propósito dessas suas Cábulas, lembra uma passagem do filme Operação Dragão, com Bruce Lee, o astro das lutas marciais no cinema nos anos de 1970. Insistentemente provocado por um desafiante, a personagem do lutador termina aceitando um confronto numa pequena ilha. Mas na hora do combate, escapa num barco e deixa o oponente sozinho, confirmando o seu declarado estilo de atuação: "a arte de lutar sem lutar".

por Thierry Freitas e Lara Rivetti 